\title{
Transcription Factor PU.1
}

National Cancer Institute

\section{Source}

National Cancer Institute. Transcription Factor PU.1. NCI Thesaurus. Code C18036.

Transcription factor PU.1 (270 aa, $31 \mathrm{kDa}$ ) is encoded by the human SPI1 gene. This protein plays a role in transcriptional regulation in hematopoietic cells. 